\title{
GABA Transaminase Inhibition Induces Spontaneous and Enhances Depolarization-Evoked GABA Efflux via Reversal of the GABA Transporter
}

\author{
Yuanming Wu, ${ }^{1}$ Wengang Wang, ${ }^{1}$ and George B. Richerson ${ }^{1,2}$ \\ 'Department of Neurology, Yale University School of Medicine, New Haven, Connecticut 06520-8018, and 2Veterans' \\ Affairs Medical Center, West Haven, Connecticut 06516
}

\begin{abstract}
The GABA transporter can reverse with depolarization, causing nonvesicular GABA release. However, this is thought to occur only under pathological conditions. Patch-clamp recordings were made from rat hippocampal neurons in primary cell cultures. Inhibition of GABA transaminase with the anticonvulsant $\gamma$-vinyl GABA (vigabatrin; 0.05-100 $\mu \mathrm{m}$ ) resulted in a large leak current that was blocked by bicuculline $(50 \mu \mathrm{M})$. This leak current occurred in the absence of extracellular calcium and was blocked by the GABA transporter antagonist SKF-89976a $(5 \mu \mathrm{M})$. These results indicate that vigabatrin induces spontaneous GABA efflux from neighboring cells via reversal of GABA transporters, subsequently leading to the stimulation of $\mathrm{GABA}_{\mathrm{A}}$ receptors on the recorded neuron. The leak current increased slowly over $4 \mathrm{~d}$ of treatment with $100 \mu \mathrm{M}$ vigabatrin, at which time it reached an equivalent conductance of $9.0 \pm 4.9 \mathrm{nS}$. Blockade of glutamic acid decarboxylase with semicarbazide (2
\end{abstract}

Neurotransmitter transporters traditionally are considered to function simply to clear their substrate from the synaptic cleft. However, many transporters can also reverse, causing the release of neurotransmitter in a calcium-independent manner (Nicholls and Attwell, 1990; Attwell et al., 1993; Levi and Raiteri, 1993). For example, the GABA transporter reverses in response to depolarization or an increase in $\left[\mathrm{Na}^{+}\right]_{\mathrm{i}}$ (Moscowitz and Cutler, 1980; Bernath and Zigmond, 1988; Pin and Bockaert, 1989; Saransaari and Oja, 1992; Belhage et al., 1993; Cammack and Schwartz, 1993; Cammack et al., 1994).

Previous studies of GABA transporter reversal typically have used nonphysiological stimuli. For example, calcium-independent GABA release has been induced by an increase in $\left[\mathrm{K}^{+}\right]_{\mathrm{o}}$ to $>50$ $\mathrm{mM}$, by $100 \mu \mathrm{M}$ glutamate, and by nipecotate (NPA) (Moscowitz and Cutler, 1980; Pin and Bockaert, 1989; Turner and Goldin, 1989; Solis and Nicoll, 1992; Belhage et al., 1993; Honmou et al., 1995). Probably for this reason, reversal of the GABA transporter has been considered to be important only during pathological conditions such as ischemia (Nicholls and Attwell, 1990; Levi and Raiteri, 1993). However, carrier-mediated GABA release can occur in response to presynaptic stimulation (Schwartz, 1987; Bernath and Zigmond, 1988) and also can occur in response to an

Received Sept. 22, 2000; revised Jan. 26, 2001; accepted Jan. 31, 2001.

This work was supported by National Institutes of Health Grant NS-06208, by the Epilepsy Foundation of America, and by the Veterans' Affairs Medical Center.

Correspondence should be addressed to Dr. George B. Richerson, Department of Neurology, LCI-704, Yale University School of Medicine, 15 York Street, P.O. Box 208018, New Haven, CT 06520-8018. E-mail: George.Richerson@Yale.Edu.

Copyright (C) 2001 Society for Neuroscience $0270-6474 / 01 / 212630-10 \$ 15.00 / 0$ $\mathrm{mm}$ ) decreased the leak current that was induced by vigabatrin by $47 \%$. In untreated cells, carrier-mediated GABA efflux did not occur spontaneously but was induced by an increase in $\left[\mathrm{K}^{+}\right]_{0}$ from 3 to as little as $6 \mathrm{~mm}$. Vigabatrin enhanced this depolarization-evoked nonvesicular GABA release and also enhanced the heteroexchange release of GABA induced by nipecotate. Thus, the GABA transporter normally operates near its equilibrium and can be easily induced to reverse by an increase in cytosolic [GABA] or mild depolarization. We propose that this transporter-mediated nonvesicular GABA release plays an important role in neuronal inhibition under both physiological and pathophysiological conditions and is the target of some anticonvulsants.

Key words: seizure; epilepsy; vigabatrin; synapse; nonvesicular; hippocampus elevation in $\left[\mathrm{K}^{+}\right]_{\mathrm{o}}$ from 3 to $12 \mathrm{~mm}$ (Gaspary et al., 1998), a level of $\left[\mathrm{K}^{+}\right]_{\mathrm{o}}$ that is reached in vivo during neuronal firing (Krnjevic et al., 1980; Somjen and Giacchino, 1985) and during seizures (Fisher et al., 1976).

The anticonvulsant $\gamma$-vinyl GABA (vigabatrin) is an irreversible antagonist of GABA transaminase and induces an increase in GABA levels in rat and human brain (Schechter et al., 1977; Ben-Menachem et al., 1993; Loscher and Horstermann, 1994; Preece et al., 1994; Petroff et al., 1996). Often it is assumed that the increase in brain GABA leads to increased GABAergic inhibition, explaining the anticonvulsant effect. However, exactly how this occurs is unclear. Blockade of GABA transaminase increases [GABA] within the cytoplasmic pool (Wood et al., 1988) but does not necessarily affect GABA content within synaptic vesicles or the probability of vesicular GABA release. This may explain why it has been difficult to obtain direct electrophysiological evidence for the enhancement of GABAergic IPSPs (Jackson et al., 1994; Jung and Palfreyman, 1995; Engel et al., 2000). Recently, vigabatrin has been reported to decrease activity-dependent depression of inhibition in the rat hippocampus (Jackson et al., 2000). The mechanism of this effect is unclear but may result in part from an increase in transporter-mediated GABA release, which has been measured by using other approaches (Qume et al., 1995; Yee et al., 1998). This form of GABA release can inhibit surrounding neurons (Solis and Nicoll, 1992; Gaspary et al., 1998) and thus could contribute to the anticonvulsant properties of vigabatrin.

Here we have used patch-clamp recordings from rat hippocampal neurons in primary cell cultures to measure $\mathrm{GABA}_{\mathrm{A}}$ receptor 
currents as a bioassay of carrier-mediated GABA release. Vigabatrin was found to induce spontaneous GABA release via reversal of the GABA transporter and also enhanced nonvesicular GABA release induced by an elevation in $\left[\mathrm{K}^{+}\right]_{\mathrm{o}}$. The results indicate that the GABA transporter reverses more easily than previously recognized and is highly sensitive to changes in the [GABA] gradient and membrane potential.

\section{MATERIALS AND METHODS}

Cell culture. Primary cell cultures of hippocampal neurons and glia were prepared from neonatal (P0-P2) Sprague Dawley rats as described previously (Gaspary et al., 1998). Briefly, hippocampi were dissociated, plated at a density of $2.5-5 \cdot 10^{5}$ cells/ml on poly-L-ornithine and laminin-coated coverslips, and incubated in culture medium [63\% modified Eagle's medium (MEM), 7\% fetal bovine serum (FBS), and 30\% Neurobasal medium with B27 supplement] with 3.6 gm/1 glucose, 100 $\mathrm{U} / \mathrm{ml}$ penicillin, and $100 \mu \mathrm{g} / \mathrm{ml}$ streptomycin at $37^{\circ} \mathrm{C}$ with $5 \% \mathrm{CO}_{2}$ in room air. At $24 \mathrm{hr}$ the medium was switched to $100 \%$ Neurobasal/B27. Cytosine $\beta$-D-arabino-furanoside hydrochloride (Ara C; $3 \mu \mathrm{M}$ ) was used to control glial growth after $\sim 7 \mathrm{~d}$. Cultures were fed with half-medium changes on day 7 and then weekly. Cultures were grown for at least $10 \mathrm{~d}$ before recording to permit the development of responses to NPA and elevated $\left[\mathrm{K}^{+}\right]_{0}$. Culture media, including FBS, Neurobasal medium, and B27 supplement, were purchased from Life Technologies (Gaithersburg, MD); MEM was purchased from JRH Biosciences (Lenexa, KS).

Tissue culture has many advantages compared with brain slices or in vivo experiments, such as more stability of patch-clamp recordings and better control of the extracellular space. However, neurons in these cultures were in a monolayer on the surface of a glial bed. Therefore, the cells were exposed to bath solution flowing above them, so that GABA released from their upper surface would diff use away more rapidly than in vivo. In addition, drugs applied in the bath would not have rapid access to the extracellular space between neurons and the glial bed on which they sit, because of restricted diffusion. These factors should be considered in interpreting the results. They would be likely to decrease the magnitude of the responses seen, suggesting that the already large currents measured here may underestimate the responses that would occur in vivo.

Electrophysiology. For recordings the coverslips were placed in a chamber on a fixed-stage upright light microscope (Axioskop FS, Zeiss, Oberkochen, Germany) and superfused (at 3-4 $\mathrm{ml} / \mathrm{min}$ ) with one of the following solutions. "Normal" Ringer's solution contained (in mM): 124 $\mathrm{NaCl}, 3 \mathrm{KCl}, 2 \mathrm{MgCl}_{2}, 2 \mathrm{CaCl}_{2}, 1.3 \mathrm{NaH}_{2} \mathrm{PO}_{4}, 26 \mathrm{NaHCO}_{3}$, and 10 dextrose. "Zero-calcium" Ringer's solution was the same solution except that $\mathrm{CaCl}_{2}$ was omitted and $1 \mathrm{~mm}$ EGTA was added. In most cases (except those experiments in normal Ringer's shown in Fig. 2B, gray trace), responses to bicuculline were induced in zero-calcium Ringer's solution to which tetrodotoxin (TTX; 0.5-1 $\mu \mathrm{M}$ ), 6-cyano-7-nitroquinoxaline-2,3-dione (CNQX; $10 \mu \mathrm{M})$, and ( \pm )-2-amino-5-phosphonopentanoic acid (AP-5; $50 \mu \mathrm{M})$ were added. Responses to NPA and GABA were measured in normal Ringer's solution containing $0.5 \mu \mathrm{M}$ TTX. All bath solutions were bubbled with $5 \% \mathrm{CO}_{2} / 95 \% \mathrm{O}_{2}$ at $\mathrm{pH}$ 7.4.

Whole-cell patch-clamp recordings were performed in voltage-clamp mode with a patch-clamp amplifier (Axopatch 1D, Axon Instruments, Foster City, CA). Recording electrodes (2.5-4.0 M $\Omega$ ) were fabricated from thin-walled borosilicate glass tubing (Diamond General, Ann Arbor, MI) with a micropipette puller (model P-87, Sutter Instruments, Novato, CA). For most recordings the patch-clamp electrodes contained (in mM): $135 \mathrm{CsCl}, 10 \mathrm{HEPES}$, and 1 EGTA. When the perforated patch technique was used, the intracellular solution contained (in $\mathrm{mM}$ ): 135 potassium methanesulfonate, $10 \mathrm{KCl}, 5 \mathrm{HEPES}$, and 1 EGTA. Amphotericin was added via methods that were described previously (Rae et al., 1991; Wang et al., 1998). Electrode solutions were adjusted to $\mathrm{pH} 7.2$ with either $\mathrm{KOH}$ or $\mathrm{CsOH}$ and to an osmolarity of $270 \pm 5 \mathrm{mOsm}$. The liquid junction potential was measured experimentally for these combinations of electrode and bath solutions and was $\leq 1 \mathrm{mV}$ in each case. Initial seal resistance was typically $\geq 1 \mathrm{G} \Omega$.

To assay nonvesicular GABA release, we made measurements of currents that were induced in neurons by the activation of $\mathrm{GABA}_{\mathrm{A}}$ receptors (Fig. 1). To stimulate carrier-mediated GABA release, to apply GABA directly, or to block currents induced by spontaneous GABA release, we applied solutions by using the "multipuffer" technique for the application of multiple solutions (Greenfield and Macdonald, 1996). In

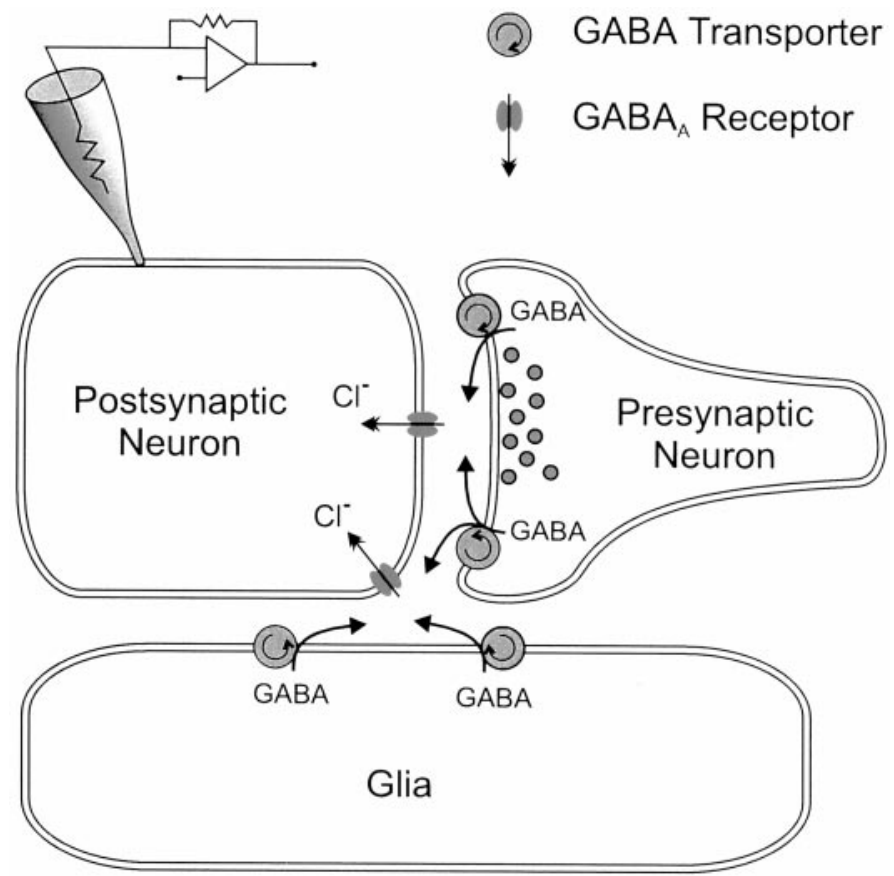

Figure 1. Schematic of recording setup. Recordings were made from neurons in primary cell cultures. When GABA was released from neighboring neurons and glia, a $\mathrm{GABA}_{\mathrm{A}}$ receptor-mediated current was measured (Gaspary et al., 1998). Conditions were used in which vesicular GABA release was blocked. Therefore, these recordings were a rapid and highly sensitive bioassay of GABA release via reversal of the GABA transporter at physiologically relevant sites.

all cases the multipuffer solution was identical to the bath solution at that time, except for the specific stimulus (NPA, $\mathrm{K}^{+}$, GABA, bicuculline, or SKF-89976a) being tested. Test solutions containing NPA, increased $\left[\mathrm{K}^{+}\right]_{\mathrm{o}}$, and GABA were applied for 5 sec. Test solutions containing bicuculline and SKF-89976a were applied for 20 or $60 \mathrm{sec}$. In previous experiments that used a pressure microejection electrode rather than the multipuffer technique (Gaspary et al., 1998), trypan blue (0.4\%) was added to the microejection solutions to allow for visualization of the flow. In the current set of experiments that used the multipuffer technique, the flow of solution out of the pipette was visualized and adjusted by using Ringer's solution containing trypan blue; then the response was induced with test solutions that did not contain trypan blue. Application of the bath solution alone with the multipuffer had no effect $(n=10)$.

When examining the response to elevated $\left[\mathrm{K}^{+}\right]_{\mathrm{o}}$, we designed the electrode and bath solutions to block all currents in the recorded neuron except those mediated by $\mathrm{GABA}_{\mathrm{A}}$ receptors and to block vesicular GABA release, as described previously (Gaspary et al., 1998). These solutions included: (1) $N$-(2,6-dimethylphenylcarbamoylmethyl)triethylammonium chloride (QX-314) (Connors and Prince, 1982) in the recording electrode to block $\mathrm{Na}^{+}$currents; (2) $\mathrm{Cs}^{+}$in the electrode solution to block most $\mathrm{K}^{+}$currents; (3) EGTA and no added $\mathrm{Ca}^{2+}$ in the bath solution to block calcium currents and vesicular release; and (4) CNQX and AP-5 in the bath solution to block glutamate receptors. Thus, electrodes contained (in mM): $114 \mathrm{CsCl}, 20$ QX-314 chloride, 10 HEPES, and 10 EGTA, pH 7.2. The bath solution contained (in $\mathrm{mM}$ ): $128 \mathrm{NaCl}$, $3 \mathrm{KCl}, 2 \mathrm{MgCl}_{2}, 1.3 \mathrm{NaH}_{2} \mathrm{PO}_{4}, 22 \mathrm{NaHCO}_{3}, 10$ dextrose, 1 EGTA, 0.05 AP-5, and $0.01 \mathrm{CNQX}, \mathrm{pH}$ 7.4. The elevated $\left[\mathrm{K}^{+}\right]_{\mathrm{o}}$ solution applied via the multipuffer was identical to the bath solution, except that $\mathrm{KCl}$ was increased to $6,9,12$, or $25 \mathrm{~mm}$; $\mathrm{NaCl}$ was decreased by an equimolar amount. As shown previously by the use of these same methods (Gaspary et al., 1998), an increase in $\left[\mathrm{K}^{+}\right]_{\mathrm{o}}$ to $12 \mathrm{~mm}$ induces a chloride current that is blocked by bicuculline (this was confirmed again here; $n=11$ ). This response is calcium-independent, occurs after treatment with tetanus toxin, and is blocked by GABA transporter antagonists (Gaspary et al., 1998). Thus, the current induced under these conditions is attributable to the activation of $\mathrm{GABA}_{\mathrm{A}}$ receptors by GABA that is released through GABA transporters on neighboring cells as a result of the $\mathrm{K}^{+}$-induced depolarization. As described previously (Gaspary et al., 
1998), the GABA release is not from the recorded neuron, because there is no GABA in the recording pipette and the neuron is clamped at a constant voltage.

Recordings usually were made from only three neurons per coverslip, and coverslips were discarded within $3 \mathrm{hr}$ from the time that they were removed from the incubator. Values expressed as $n=x$ are the total number of neurons recorded, unless otherwise indicated. Experiments were performed at room temperature $\left(24^{\circ} \mathrm{C}\right)$. AP-5, CNQX, and nipecotic acid (NPA) were purchased from Research Biochemicals (RBI, Natick, MA). QX-314 and TTX were purchased from Alomone Labs (Jerusalem, Israel). CGP-55845 was purchased from Tocris Cookson (Ballwin, MO). All salts and chemicals not otherwise listed were purchased from Sigma (St. Louis, MO).

Drug treatment. Culture wells that contained $1 \mathrm{ml}$ of medium were supplemented with culture medium to which vigabatrin was added in the appropriate concentration (using a $10-100 \times$ stock solution) and then were maintained in the incubator until recording. Control recordings were made from paired sister coverslips (cells cultured the same day), chosen as having a similar cell density. Control coverslips were fed with the same volume of fresh medium as their sister coverslips. From the time coverslips were placed in the recording chamber, they were superfused with bath solution that did not contain vigabatrin so that any observed effects were not a result of the direct, reversible actions of the drug (Jolkkonen et al., 1992; Jung and Palfreyman, 1995; Jackson et al., 2000). The individual responsible for the selection of coverslips for feeding, for making recordings, and for data analysis was blinded to the specific drugs and concentrations that were used for preincubation of the coverslips.

Data analysis. Responses were measured by recording the holding current in voltage clamp at a holding potential of $-60 \mathrm{mV}$. Data were digitized and stored on computer via a commercially available data acquisition system (TL-1 DMA interface and pClamp software, Axon Instruments). The peak amplitude and the area under the curve (AUC) of the current response to each of the stimuli were calculated as described previously (Gaspary et al., 1998). For responses to bicuculline the analysis was performed on peak amplitudes, because this would permit the best estimate of the number of $\mathrm{GABA}_{\mathrm{A}}$ receptors that had been activated. For responses to NPA and increased $\left[\mathrm{K}^{+}\right]_{\mathrm{o}}$ the analysis was performed on the AUC, because it was assumed that this was a better measure of the total amount of GABA released. The AUC of the responses, or total charge transfer, was expressed in nanocoulombs $(\mathrm{nC}=$ nanoamperes $\cdot \mathrm{sec})$. The average responses for groups of neurons (see Figs. $6 B, 9 B$ ) were calculated as the mean current at each time point from all neurons within a group. Baseline leak was subtracted when these composite currents were calculated. Probability values were determined by using Student's $t$ test. All values expressed as $x \pm y$ are mean $\pm \mathrm{SD}$; all error bars are SEM.

\section{RESULTS}

\section{Inhibition of GABA transaminase induced spontaneous nonvesicular GABA release}

When recordings were made in zero-calcium Ringer's from dishes that had been treated with $100 \mu \mathrm{M}$ vigabatrin for $79.6 \pm 12.5 \mathrm{hr}$, a large leak current $(-1194 \pm 603 \mathrm{pA} ; n=31)$ was present at a holding potential of $-60 \mathrm{mV}$. Although a large leak current during patch-clamp recordings is typically nonspecific and can occur when cells are unhealthy, the neurons appeared healthy under the microscope, and the patch-clamp seals were of high resistance before whole-cell breakthrough. When bicuculline (50 $\mu \mathrm{M})$ was applied with the multipuffer, the leak current was decreased by $542 \pm 294$ pA ( $n=29$; two examples are shown in Fig. $2 A$ ). Based on a calculated reversal potential for the $\mathrm{GABA}_{\mathrm{A}}$ receptor of $0 \mathrm{mV}$ and the holding potential of $-60 \mathrm{mV}$, the conductance change required to induce this GABA-mediated leak current was estimated to be $9.0 \pm 4.9 \mathrm{nS}$. In contrast, the leak current in control hippocampal neurons was smaller $(-563 \pm 450$ $\mathrm{pA} ; n=30)$, and the application of bicuculline had no significant effect (change in leak current, $12.8 \pm 67 \mathrm{pA} ; n=25$ ). After the application of bicuculline the leak current was approximately equal in vigabatrin-treated and control neurons.
A

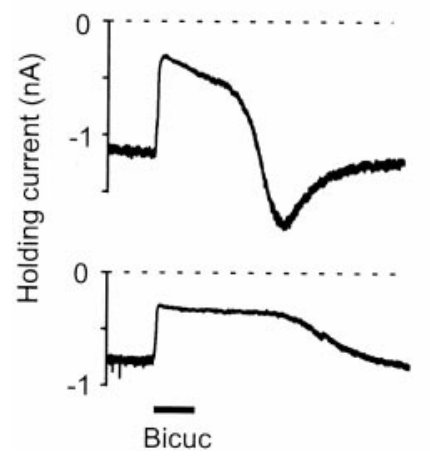

B

Figure 2. Vigabatrin caused spontaneous, tonic $\mathrm{GABA}_{\mathrm{A}}$ receptor activation attributable to calcium-independent GABA release. $A$, Examples of recordings from two neurons on culture dishes that had been treated with $100 \mu \mathrm{M}$ vigabatrin for $4 \mathrm{~d}$. Recordings are in zero-calcium Ringer's solution. In both cases a large amount of negative current was required to hold the membrane potential at $-60 \mathrm{mV}$ in voltage clamp. At the bar, bicuculline $(50 \mu \mathrm{M})$ decreased the holding current in both neurons. In some neurons, such as the top example, there was a sag in the response to bicuculline and a rebound increase in holding current after bicuculline application. This may have been attributable to a reduction in desensitization of the $\mathrm{GABA}_{\mathrm{A}}$ receptor by bicuculline. $B$, The amount of leak current that was blocked by bicuculline $(50 \mu \mathrm{M})$ was approximately the same in the presence and in the absence of extracellular calcium. Dark trace, Zero-calcium Ringer's solution; gray trace, normal Ringer's solution.

The blockade of leak current by bicuculline indicates that $\mathrm{GABA}_{\mathrm{A}}$ receptors were activated tonically because of continuous efflux of GABA from neighboring neurons and/or glia. To determine the effect of calcium on this GABA release, we measured the response to bicuculline $(50 \mu \mathrm{M})$ in both normal Ringer's and in zero-calcium Ringer's in the same set of neurons $(n=21)$. The leak current blocked by bicuculline in zero-calcium Ringer's was $77 \pm 38 \%$ of that in normal Ringer's (Fig. $2 B ; p<0.05$; dishes pretreated with $100 \mu \mathrm{M}$ vigabatrin for $105 \pm 15 \mathrm{hr}$ ). Fast IPSPs also were not seen during most recordings, and the leak current was manifest as a constant offset in the holding current. Thus, the spontaneous leak current was primarily attributable to nonvesicular GABA release.

\section{GABA efflux inhibited neighboring neurons}

GABA usually inhibits neurons. However, under some conditions $\mathrm{GABA}_{\mathrm{A}}$ receptor stimulation can depolarize neurons (Cherubini et al., 1991; Staley et al., 1995; Rivera et al., 1999). Whether GABA is inhibitory or excitatory depends on the ionic gradients across the membranes that contain the $\mathrm{GABA}_{\mathrm{A}}$ receptors. In the current experiments with whole-cell recordings, the chloride concentrations were determined experimentally by the recording solutions that were used and resulted in a predicted reversal potential for the $\mathrm{GABA}_{\mathrm{A}}$ receptor of $0 \mathrm{mV}$, so GABA caused a depolarizing response. To determine whether GABA efflux induced by vigabatrin inhibits these neurons when they maintain their own chloride gradient, we made recordings using the perforated patch technique (Rae et al., 1991). To eliminate confounding effects of $\mathrm{GABA}_{\mathrm{B}}$ receptor activation, we included the $\mathrm{GABA}_{\mathrm{B}}$ receptor antagonist CGP-55845 $(1 \mu \mathrm{M})$ in the bath solution for all of the perforated patch recordings that are described here. With the use of this approach in neurons that had been treated with $100 \mu \mathrm{M}$ vigabatrin for $6.2 \pm 2.4 \mathrm{~d}(n=14)$, bicuculline $(50-100 \mu \mathrm{M})$ resulted in blockade of an outward (inhibitory) leak current in zero-calcium Ringer's at a holding 


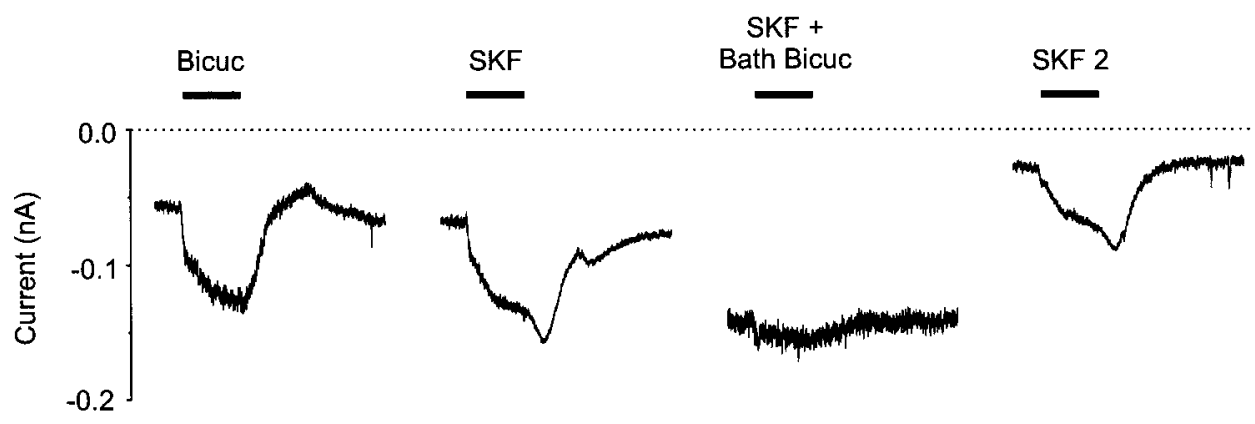

B

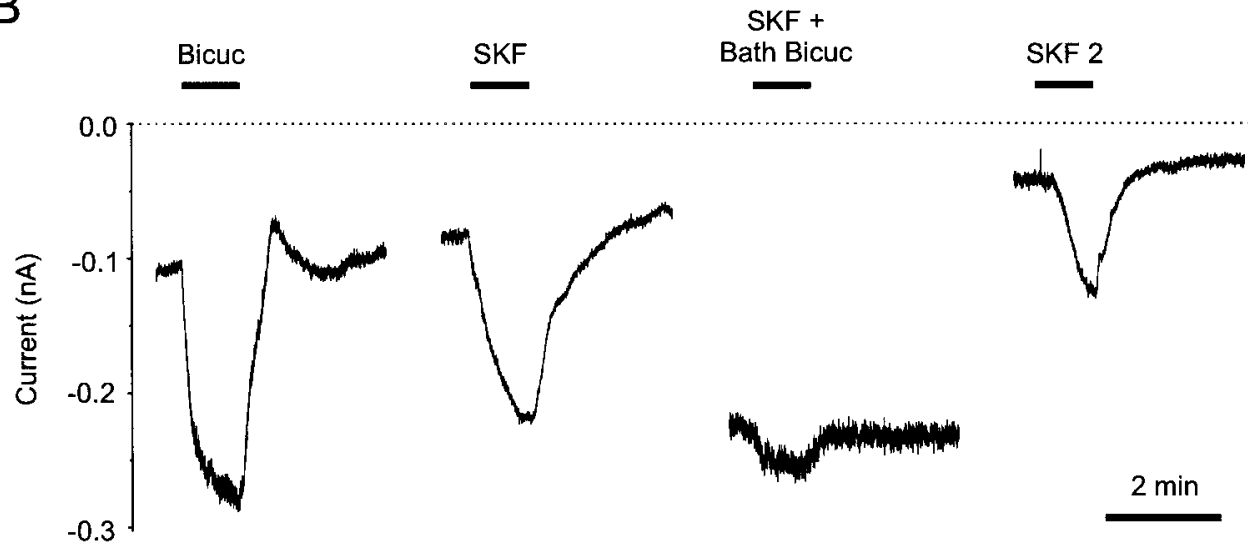

Figure 3. Tonic GABA release induced by vigabatrin caused the inhibition of neighboring neurons and was a result of the GABA transporter operating in reverse. $A$, Perforated patch recording from a neuron on a culture dish that had been treated with $100 \mu \mathrm{M}$ vigabatrin for $165 \mathrm{hr}$. The recording was made at a holding potential of $-60 \mathrm{mV}$ in zero-calcium Ringer's solution that contained TTX, CNQX, AP-5, and CGP-55845. Application of bicuculline $(100 \mu \mathrm{M})$ led to a decrease in an outward current (Bicuc), indicating that the tonic leak current induced by $\mathrm{GABA}_{\mathrm{A}}$ receptor stimulation caused inhibition of this neuron. Application of SKF$89976 \mathrm{a}(5 \mu \mathrm{M})$ also caused a decrease in outward current $(S K F)$, consistent with the blockade of GABA release by the transporter. After block of the outward leak current with bicuculline $(100 \mu \mathrm{M})$ in the bath solution, the response to SKF$89976 \mathrm{a}(5 \mu \mathrm{M})$ was decreased $(S K F+$ Bath Bicuc). The block of the response to SKF-89976a by bicuculline was reversible (SKF 2). B, Example of a second neuron with the same protocol. This neuron was treated with vigabatrin for $64 \mathrm{hr}$. Similar results were obtained from a total of 14 neurons. potential of $-60 \mathrm{mV}$ (Fig. 3). In these neurons there was a baseline inward leak current of $0.10 \pm 0.09 \mathrm{nA}$, and the outward current blocked by bicuculline was $0.14 \pm 0.08 \mathrm{nA}$. This $\mathrm{GABA}_{\mathrm{A}}$ receptor-mediated current was smaller than when whole-cell recordings were used, consistent with a smaller difference between the holding potential and the Nernst potential for chloride. When the same experiment was repeated with perforated patch recordings using the chloride impermeable ionophore gramicidin instead of amphotericin (Kyrozis and Reichling, 1995), bicuculline $(50 \mu \mathrm{M})$ also resulted in a decrease in the outward leak current ( $n$ $=6$ ). The fact that tonic GABA release induced an inhibitory current in these neurons does not rule out the possibility that vigabatrin-induced GABA efflux may stimulate some neurons under different conditions.

\section{Tonic GABA efflux was mediated by the GABA transporter operating in reverse}

We hypothesized that calcium-independent GABA release induced by vigabatrin was attributable to reversal of the GABA transporter. If this were the case, antagonists of the GABA transporter should reduce the tonic $\mathrm{GABA}_{\mathrm{A}}$ receptor-mediated current induced by vigabatrin. To test this possibility, we used the GABA transporter antagonist SKF-89976a because it blocks influx and efflux through the transporter and has not been reported to cause heteroexchange release of GABA (Mager et al., 1993; Cammack et al., 1994).

After the response to bicuculline was measured by using the perforated patch technique, SKF-89976a (5 $\mu \mathrm{M})$ was applied with the multipuffer to the same neurons $(n=14)$. This also resulted in the block of an outward leak current (Fig. 3), in this case with a magnitude of $0.10 \pm 0.05 \mathrm{nA}$ or $69 \%$ of the response to bicuculline. The likely reason for this response to SKF-89976a was a decrease in GABA release and subsequent decrease in $\mathrm{GABA}_{\mathrm{A}}$ receptor stimulation. Consistent with this explanation, when bicuculline $(50-100 \mu \mathrm{M})$ was applied in the bath solution, there was a shift in the holding current; then the response to SKF-89976a was reversibly decreased (Fig. 3; $n=14$ ). This is what would be predicted, because preventing GABA release would have no effect after $\mathrm{GABA}_{\mathrm{A}}$ receptors had been blocked first by bicuculline (and $\mathrm{GABA}_{\mathrm{B}}$ receptors had been blocked with CGP55845). Two examples of neurons that were tested for their response to both bicuculline and SKF-89976a are shown in Figure 3.

\section{The effect of vigabatrin increased slowly and was concentration-dependent}

It took several days for vigabatrin to induce its full effect on tonic GABA release. For example, when recordings were made from dishes treated with vigabatrin $(100 \mu \mathrm{M})$ for $19.5 \pm 2.0 \mathrm{hr}$, the magnitude of the leak current blocked by bicuculline $(50 \mu \mathrm{M})$ in zero-calcium Ringer's was $267 \pm 24 \mathrm{pA}(n=6)$. This GABA receptor-mediated leak current increased steadily over 4-5 d of treatment, reaching $637 \pm 338 \mathrm{pA}(n=11)$ after $109 \pm 12 \mathrm{hr}$ (Fig. $4 A$ ). The leak current blocked by bicuculline was different for all time points as compared with control $(p<0.001)$, for $109 \mathrm{hr}$ as compared with $46 \mathrm{hr}(p<0.05)$, and for $70 \mathrm{hr}$ as compared with $46 \mathrm{hr}(p<0.05)$. Values of $n$ not listed above were 22 (control), 12 (46 hr), and 14 (70 hr).

A vigabatrin concentration of $100 \mu \mathrm{M}$ has been considered to be clinically relevant (Gram et al., 1988). However, because of its unusual pharmacology it is not clear how to compare the concentration during continuous exposure of cells in culture with the blood levels in vivo. Therefore, we examined the effect of a range 
A

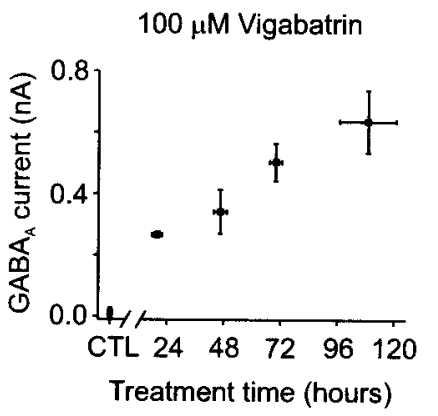

B

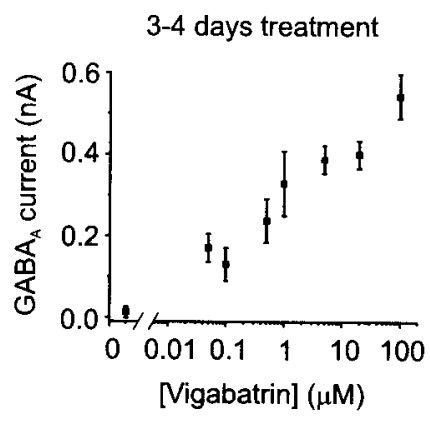

Figure 4. The spontaneous, tonic nonvesicular GABA release induced by vigabatrin required 3-4 d of treatment to develop fully and occurred at nanomolar concentrations. $A$, The nonvesicular GABA release induced by vigabatrin increased very slowly. Plotted is the component of leak current that was blocked by bicuculline $(50 \mu \mathrm{M})$ in neurons that had been treated with $100 \mu \mathrm{M}$ vigabatrin for variable times, up to $5 \mathrm{~d}$. The response to bicuculline in treated neurons was significantly greater than in control neurons $(C T L)$ for all time points $(p<0.001) . B$, GABA leak current was induced by low concentrations of vigabatrin. Plotted is the leak current blocked by bicuculline $(50 \mu \mathrm{M})$ versus the concentration of vigabatrin to which cells in culture were exposed for 3-4 d. Spontaneous GABA release was induced by as little as $50 \mathrm{~nm}$ vigabatrin and increased progressively with increasing concentrations up to $100 \mu \mathrm{M}$. All points are significantly greater for vigabatrin-treated cultures as compared with control $(p<0.001)$.

of vigabatrin concentrations on tonic GABA efflux. Cells were exposed to concentrations of vigabatrin ranging from $50 \mathrm{~nm}$ to $100 \mu \mathrm{M}$ for $3-4 \mathrm{~d}$ (mean duration of exposure, $81.3 \pm 12 \mathrm{hr}$; no significant difference in treatment duration between concentration groups). The leak current that was blocked by bicuculline (50 $\mu \mathrm{M})$ in zero-calcium Ringer's increased with increasing concentrations of vigabatrin (Fig. $4 \mathrm{~B}$ ), with as little as $50 \mathrm{~nm}$ sufficient to cause a statistically significant increase in tonic GABA release $[p<0.001$; all other concentrations also significantly different from control; values of $n$ were $25(0 \mu \mathrm{M}), 12(0.05 \mu \mathrm{M}), 9(0.1 \mu \mathrm{M})$, $11(0.5 \mu \mathrm{M}), 12(1 \mu \mathrm{M}), 25(5 \mu \mathrm{M}), 24(20 \mu \mathrm{M})$, and $29(100 \mu \mathrm{M})]$.

\section{Tonic GABA efflux was decreased by the inhibition of glutamic acid decarboxylase}

The most likely explanation for the effect of vigabatrin is that it increased cytosolic [GABA] and thus increased the driving force for reversal of the GABA transporter. If this were the case, then the effect of vigabatrin should be antagonized by agents that block the synthesis of GABA. To determine whether this was true, we preincubated cells with vigabatrin with or without semicarbazide, an antagonist of glutamic acid decarboxylase (GAD) (Meldrum, 1975).

After treatment with $5 \mu \mathrm{M}$ vigabatrin for $79 \pm 12 \mathrm{hr}$, the leak current that was blocked by bicuculline $(50 \mu \mathrm{M})$ was $495 \pm 205 \mathrm{pA}$ (Fig. $5 ; n=11$ ). After treatment of sister dishes with $5 \mu \mathrm{M}$ vigabatrin for $82 \pm 12 \mathrm{hr}$, along with $2 \mathrm{~mm}$ semicarbazide for the last $58 \pm 12 \mathrm{hr}$ before recording, the leak current that was blocked by bicuculline was $263 \pm 129 \mathrm{pA}(n=11)$ or $53 \%$ of the response in dishes treated with vigabatrin alone $(p<0.005)$.

\section{Vigabatrin enhanced heteroexchange GABA release induced by NPA}

An increase in cytosolic [GABA] would be predicted to induce an increase in heteroexchange GABA release (Solis and Nicoll, 1992; Honmou et al., 1995). To determine whether this was true, we incubated cultured cells with $100 \mu \mathrm{M}$ vigabatrin for 12-24 hr and measured the response to NPA $(10 \mathrm{~mm})$. In dishes treated

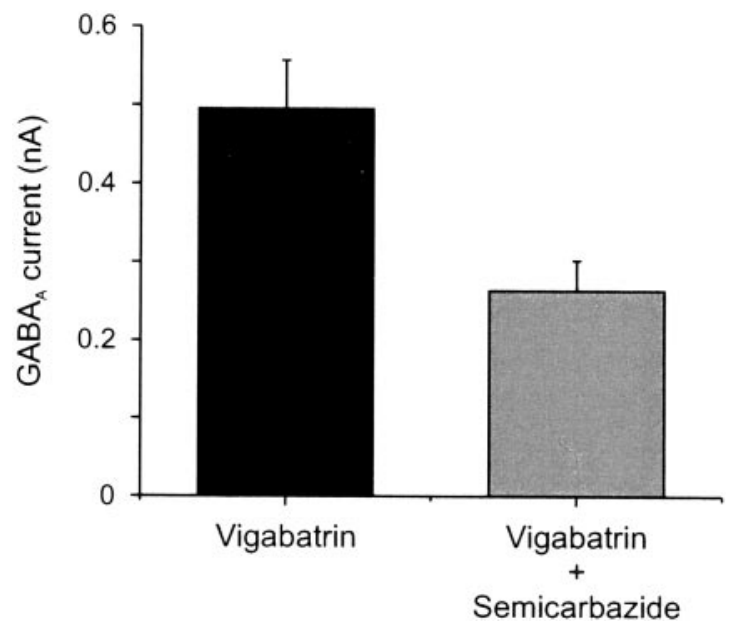

Figure 5. Blockade of glutamic acid decarboxylase decreased the tonic GABA release induced by vigabatrin. Plotted is the magnitude of the response to bicuculline $(50 \mu \mathrm{M})$ in neurons from culture dishes that were treated with $5 \mu \mathrm{M}$ vigabatrin for 3-4 d as compared with the response of sister dishes that were treated with $5 \mu \mathrm{M}$ vigabatrin for 3-4 d and also treated with semicarbazide $(2 \mathrm{~mm})$ starting $24 \mathrm{hr}$ after treatment with vigabatrin. The response of neurons that were treated with semicarbazide was $53 \%$ of control $(p<0.005)$.

with vigabatrin the response to NPA was significantly larger than in control dishes. The peak amplitude of the NPA response in vigabatrin-treated neurons was $216 \pm 50 \%$ of that in control neurons, and the AUC in vigabatrin-treated neurons was $191 \pm$ $54 \%$ of that in control neurons $(n=8$ coverslips with at least three neurons each; $p<0.002$ for both values). The magnitudes of these NPA responses were calculated after first subtracting the total baseline leak current (including that induced by vigabatrin). Thus, this increase in heteroexchange GABA release was superimposed on the tonic leak of GABA that was induced by vigabatrin.

Treatment with vigabatrin also altered the waveform of the response to NPA application, as can be seen by comparing the response in a single neuron from a vigabatrin-treated dish with that of a single control neuron (Fig. 6A). To determine how consistent this was, we averaged the NPA-induced currents for 32 neurons treated with $100 \mu \mathrm{M}$ vigabatrin for $12-24 \mathrm{hr}$ and compared them with those for 31 untreated neurons in sister dishes (Fig. 6B; baseline leak current was subtracted). Compared with control neurons, the NPA response in neurons from dishes treated with vigabatrin had a more rapid onset (time to peak: vigabatrin, $1.78 \pm 0.67 \mathrm{sec}, n=32$; control, $5.06 \pm 4.08 \mathrm{sec}, n=$ $31 ; p<0.0001$ ), a sharper peak response, and a prominent hump during the recovery (Fig. $6 A, B$ ).

To determine how NPA-induced GABA release depended on vigabatrin concentration, we incubated cultured cells with different concentrations of vigabatrin for 12-24 hr. Vigabatrin led to a dose-dependent increase in the response to NPA (10 mM; Fig. $6 C$ ), with a concentration as low as $20 \mu \mathrm{M}$ inducing a significant increase in the AUC of the response to $146 \pm 45 \%$ of control $(p<0.05)$. Values of $n$ (number of coverslips with at least three neurons each) were $7(1 \mu \mathrm{M}), 6(5 \mu \mathrm{M}), 5(20 \mu \mathrm{M}), 6(50 \mu \mathrm{M}), 8$ $(100 \mu \mathrm{M})$, and $7(400 \mu \mathrm{M})$. After $3-4 \mathrm{~d}$ of treatment the response to NPA was affected by even lower concentrations of vigabatrin (Fig. 6D). In cells that were treated with $1 \mu \mathrm{M}$ vigabatrin for $78 \pm$ $13 \mathrm{hr}$, the AUC of the response to $1 \mathrm{~mm}$ NPA was increased to 
A

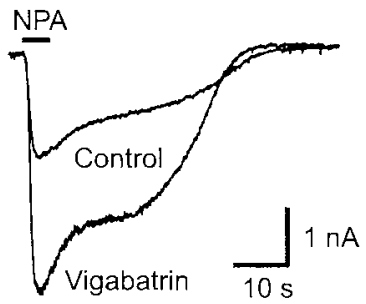

B

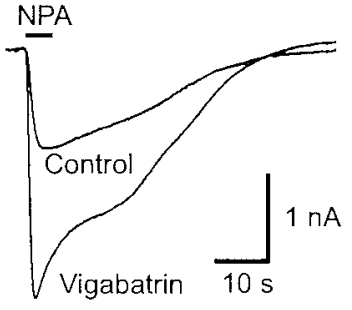

C

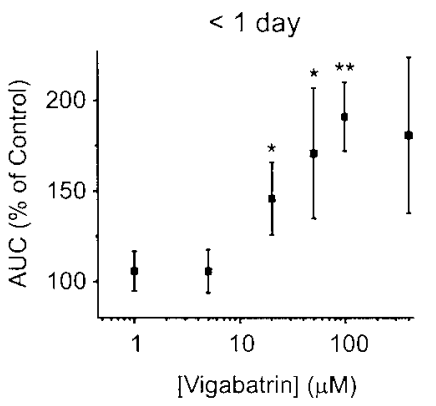

D

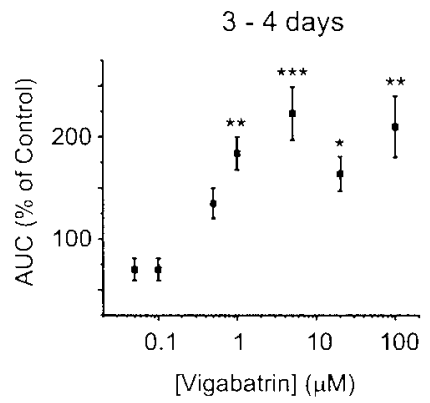

Figure 6. Vigabatrin enhanced heteroexchange GABA release. $A$, Comparison of the response to $10 \mathrm{~mm}$ NPA of a neuron on a dish treated overnight with vigabatrin $(100 \mu \mathrm{M})$ with that of a control neuron from a sister dish. $B$, Composite average of the responses to $10 \mathrm{~mm} \mathrm{NPA}$ for neurons treated with $100 \mu \mathrm{M}$ vigabatrin overnight $(n=32)$ as compared with the responses for control neurons $(n=31)$. Baseline was leaksubtracted in $A$ and $B$. $C$, NPA response versus [vigabatrin] at $<1 \mathrm{~d}$. The AUC (i.e., total charge transfer) of the response to $10 \mathrm{~mm}$ NPA was plotted as the percentage of control. Neurons were treated with different concentrations of vigabatrin for $12-24 \mathrm{hr}$. $D$, NPA response versus [vigabatrin] at 3-4 d. Plotted is the AUC (as percentage of control) of the mean responses to $1 \mathrm{~mm} \mathrm{NPA}$ for neurons that were treated with different concentrations of vigabatrin for 3-4 d. Neurons in $D$ are the same as those in Figure $4 B\left({ }^{*} p<0.05 ; * * p<0.01 ; * * p<0.001\right)$.

$184 \pm 54 \%$ of control $(p<0.01)$. In cells that were treated with $100 \mu \mathrm{M}$ vigabatrin, the AUC of the response to $1 \mathrm{mM}$ NPA was increased to $210 \pm 96 \%$ of control $(p<0.01)$. Values of $n$ were 18 (control), $12(0.05 \mu \mathrm{M}), 10(0.1 \mu \mathrm{M}), 13(0.5 \mu \mathrm{M}), 11(1 \mu \mathrm{M}), 27$ $(5 \mu \mathrm{M}), 25(20 \mu \mathrm{M})$, and $10(100 \mu \mathrm{M})$.

The enhancement of the NPA response by vigabatrin was not affected by the length of time the cells were in the recording chamber (in recording solution that did not contain vigabatrin), which would be predicted on the basis of the irreversible mechanism of vigabatrin (Jung and Palfreyman, 1995) and the long time needed to synthesize new protein to reverse its effect.

To determine whether heteroexchange GABA release is increased rapidly on acute exposure to vigabatrin, we made recordings from neurons on dishes exposed to vigabatrin in the bath solution only from the time of whole-cell breakthrough. The response to NPA $(10 \mathrm{~mm})$ was measured at the onset of recording and then every $5 \mathrm{~min}$. This same protocol previously has been shown to detect an increase in heteroexchange GABA release on acute exposure to gabapentin (Honmou et al., 1995). With the use of this protocol there was no immediate or direct effect on the response to NPA $(10 \mathrm{~mm})$ within the first $45 \mathrm{~min}$ of exposure to vigabatrin (vigabatrin-treated: $45 \pm 22 \%$ of initial response, $n=$ 6; control: $67 \pm 21 \%$ of initial response, $n=6$; difference not significant).

A

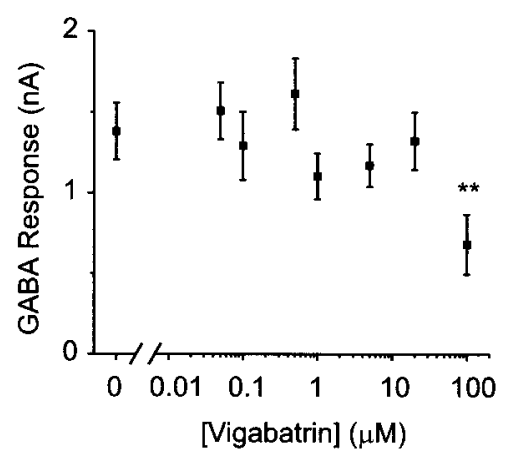

B

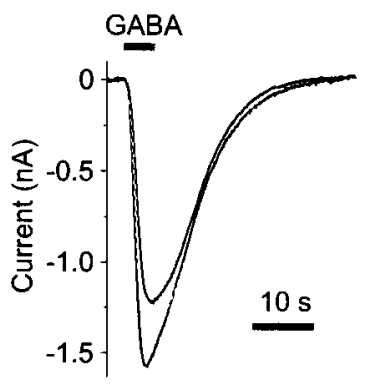

Figure 7. The sensitivity of the $\mathrm{GABA}_{\mathrm{A}}$ receptor was decreased by treatment with a high concentration of vigabatrin. $A$, Shown is the peak response to direct application of $2 \mu \mathrm{M}$ GABA in neurons from cultures that had been treated with $100 \mu \mathrm{M}$ vigabatrin for $3-4 \mathrm{~d}\left({ }^{* *} p<0.001\right)$. These are the same neurons as shown in Figures $4 B$ and $6 D$. $B$, Treatment with $100 \mu \mathrm{M}$ vigabatrin overnight led to a trend toward a smaller peak response to direct application of $2 \mu \mathrm{M}$ GABA that was not statistically significant $(p=0.06)$. Shown is the mean response from 31 vigabatrintreated neurons and 28 control neurons. Baseline was leak-subtracted in $B$. This is the same set of neurons as in Figure $6 B$.

\section{GABA efflux led to $\mathrm{GABA}_{A}$ receptor desensitization at the highest concentration of vigabatrin}

$\mathrm{GABA}_{\mathrm{A}}$ receptor desensitization would be expected to occur in response to tonic stimulation by sufficiently high concentrations of GABA. To determine whether this occurred in response to the tonic GABA efflux induced by vigabatrin, we measured currents in response to the direct application of $2 \mu \mathrm{M}$ GABA from the same neurons that were used to measure the NPA response. After $1 \mathrm{~d}$ of treatment with vigabatrin the response to the direct application of $2 \mu \mathrm{M}$ GABA was not significantly different from the control at any concentration of vigabatrin. However, there was a trend toward a decrease in the response to GABA at the highest concentrations of vigabatrin. For example, after treatment with $100 \mu \mathrm{M}$ vigabatrin the response to $2 \mu \mathrm{M}$ GABA was $1243 \pm 751$ pA (Fig. $7 B ; n=31$ ) as compared with $1562 \pm 1139$ pA in controls $(n=28 ; p=0.22$; same set of neurons as in Fig. $6 B)$. After 3-4 d of treatment with $100 \mu \mathrm{M}$ vigabatrin the response to the direct application of $2 \mu \mathrm{M}$ GABA was significantly smaller than controls $(p<0.01$; Fig. $7 A)$. In some neurons that were treated with high concentrations of vigabatrin, there was relaxation in the block of tonic leak current by bicuculline as well as an overshoot after recovery from bicuculline block (see Fig. 2A, top trace), which may have represented a decrease in desensitization as a result of the binding of bicuculline to the $\mathrm{GABA}_{\mathrm{A}}$ receptor. Desensitization of the $\mathrm{GABA}_{\mathrm{A}}$ receptor because of tonic release of GABA would have led to an underestimate of the effect of vigabatrin on the response to NPA.

It is possible that some desensitization was also present at lower concentrations of vigabatrin but was not detected with the current approach. Because the effect of vigabatrin required many days of treatment, it was necessary to make control recordings from a different set of neurons than those that were treated. Because of variability of the GABA response between individual neurons, this made it more difficult to detect small amounts of desensitization than if the response could have been measured in single neurons before and after treatment. However, if desensitization did occur, it would likely have had a minor effect compared with the large increase in inhibition induced by vigabatrin. 


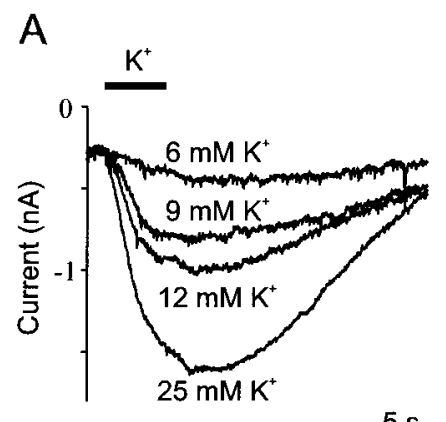

$5 \mathrm{~s}$

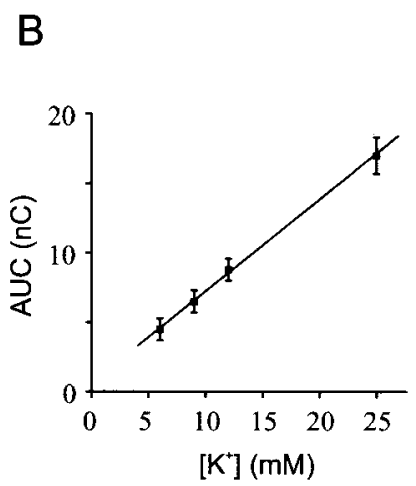

Figure 8. The GABA transporter reversed easily in untreated cells in response to potassium-induced depolarization. $A$, Responses of a single neuron to graded increases in $\left[\mathrm{K}^{+}\right]_{\mathrm{o}}$. This neuron had not been exposed to vigabatrin. The recording was made in zero-calcium Ringer's solution. As shown previously with this protocol (Gaspary et al., 1998), the currents induced by increased $\left[\mathrm{K}^{+}\right]_{\mathrm{o}}$ result from $\mathrm{GABA}_{\mathrm{A}}$ receptor activation because of carrier-mediated GABA release. $B$, The amount of carriermediated GABA release was proportional to the level of $\left[\mathrm{K}^{+}\right]_{\mathrm{o}}$, with a response induced by a rise in $\left[\mathrm{K}^{+}\right]_{\mathrm{o}}$ to as little as $6 \mathrm{~mm}$. Plotted is the total charge transfer measured as the AUC of the response for data that were obtained from 24 neurons; all points significantly differ from each other at $p<0.05$ or less.

\section{Carrier-mediated GABA release was induced by a small increase in $\left[\mathrm{K}^{+}\right]_{\text {o }}$ in untreated cells}

NPA application is a convenient method for inducing carriermediated GABA release, but an increase in $\left[\mathrm{K}^{+}\right]_{\mathrm{o}}$ is a more physiologically relevant stimulus for inducing this nonvesicular GABA release (Gaspary et al., 1998). To determine the threshold for potassium-induced nonvesicular GABA release, we examined the effect of graded increases in $\left[\mathrm{K}^{+}\right]_{\mathrm{o}}$ on cells that had not been treated with vigabatrin. The experimental conditions used for these experiments were those previously reported (Gaspary et al., 1998), in which vesicular GABA release was prevented, and all currents in the recorded neuron were blocked other than those mediated by chloride. As described above (see Materials and Methods), the current activated by an increase in $\left[\mathrm{K}^{+}\right]_{\mathrm{o}}$ via this protocol results from the stimulation of $\mathrm{GABA}_{\mathrm{A}}$ receptors because of carrier-mediated GABA release from neighboring cells. Using this approach in untreated cells, nonvesicular GABA release was induced by an increase in $\left[\mathrm{K}^{+}\right]_{0}$ from 3 to as little as 6 $\mathrm{mm}$ (Fig. $8 A$ ). This response increased progressively with increasing $\left[\mathrm{K}^{+}\right]_{\mathrm{o}}$ (Fig. $8 B$ ), with the AUC of the current induced by $\left[\mathrm{K}^{+}\right]_{\mathrm{o}}$ equal to $4.5 \pm 3.5 \mathrm{nC}$ for $6 \mathrm{~mm}\left[\mathrm{~K}^{+}\right]_{\mathrm{o}}(n=21), 6.5 \pm 3.7$ $\mathrm{nC}$ for $9 \mathrm{~mm}\left[\mathrm{~K}^{+}\right]_{\mathrm{o}}(n=24), 8.8 \pm 3.7 \mathrm{nC}$ for $12 \mathrm{~mm}\left[\mathrm{~K}^{+}\right]_{\mathrm{o}}(n=$ $24)$, and $17.0 \pm 6.5 \mathrm{nC}$ for $25 \mathrm{~mm}\left[\mathrm{~K}^{+}\right]_{\mathrm{o}}(n=24$; the data set included 24 neurons, each exposed to either three or all four concentrations of $\left[\mathrm{K}^{+}\right]_{\mathrm{o}}$ ). Thus, the GABA transporter was very sensitive to depolarization induced by a rise in $\left[\mathrm{K}^{+}\right]_{\mathrm{o}}$, with a small increase above the normal level resulting in reversal and carrier-mediated GABA release.

\section{Carrier-mediated GABA release induced by $\mathrm{K}^{+}$was enhanced by vigabatrin}

To determine whether vigabatrin also enhanced carrier-mediated GABA release induced by elevated $\left[\mathrm{K}^{+}\right]_{\mathrm{o}}$, we incubated culture dishes with vigabatrin $(100 \mu \mathrm{M})$ for $12-24 \mathrm{hr}$, and then measured the current induced by pressure microejection of a solution containing $12 \mathrm{mM}\left[\mathrm{K}^{+}\right]_{\mathrm{o}}$. The response to $12 \mathrm{mM}\left[\mathrm{K}^{+}\right]_{\mathrm{o}}$ in vigabatrintreated dishes was $193 \%$ of that in neurons from untreated
A

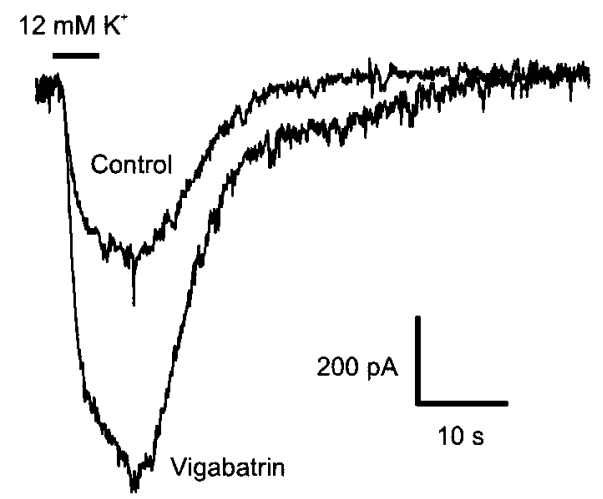

B
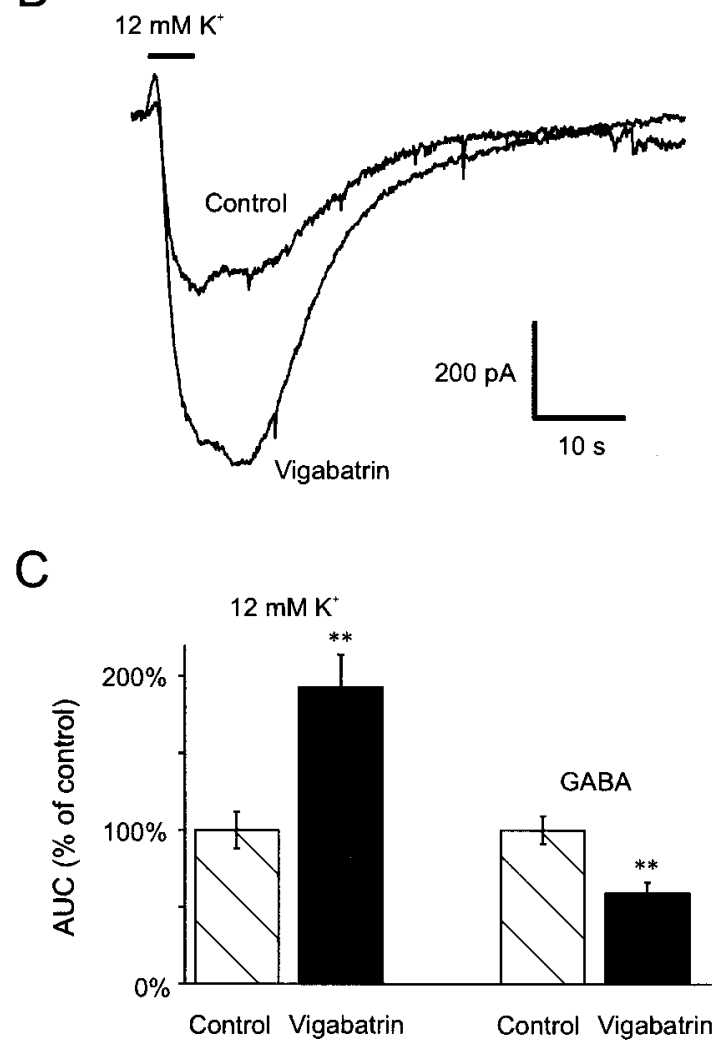

Figure 9. Vigabatrin enhanced the carrier-mediated GABA release induced by elevated $\left[\mathrm{K}^{+}\right]_{\mathrm{o}} \cdot A$, Example of the response to $12 \mathrm{~mm}\left[\mathrm{~K}^{+}\right]_{\mathrm{o}}$ (in zero-calcium solution) of a neuron on a dish treated overnight with vigabatrin $(100 \mu \mathrm{M})$ and a control neuron from a sister dish. $B$, Composite average of the responses to $12 \mathrm{mM}\left[\mathrm{K}^{+}\right]_{\mathrm{o}}$ for neurons treated with vigabatrin $(100 \mu \mathrm{M} ; n=29)$ and control neurons $(n=28)$. Baseline was leak-subtracted in $A$ and $B$. C, Vigabatrin (100 $\mu \mathrm{M}$ overnight) induced an increase in the response to $12 \mathrm{~mm}\left[\mathrm{~K}^{+}\right]_{\mathrm{o}}$ to $193 \%$ of control. The response to GABA in vigabatrin-treated neurons was $59 \%$ of control $(* * p<0.001)$.

control dishes (Fig. 9; vigabatrin-treated: $13.8 \pm 8.26 \mathrm{nC}, n=29$; control: $7.17 \pm 4.6 \mathrm{nC}, n=29 ; p<0.001)$. It is likely that the response would have been enhanced further after 3-4 d of treatment with vigabatrin. The magnitudes of the responses to increased $\left[\mathrm{K}^{+}\right]_{\mathrm{o}}$ were calculated after subtracting the total baseline leak current (including that induced by vigabatrin). Thus, the increase in $\mathrm{K}^{+}$-evoked nonvesicular GABA release was superimposed on the tonic nonvesicular GABA release induced by vigabatrin. In vigabatrin-treated dishes the response to direct appli- 
cation of $2 \mu \mathrm{M}$ GABA was $59 \%$ of the response in control dishes (vigabatrin-treated: $18.7 \pm 11.0 \mathrm{nC}, n=26$; control: $31.7 \pm 15.5$ nC, $n=26 ; p<0.001$ ), consistent with desensitization of the $\mathrm{GABA}_{\mathrm{A}}$ receptor at this higher concentration.

\section{DISCUSSION}

The anticonvulsant vigabatrin induced continuous, spontaneous efflux of GABA from hippocampal cells via reversal of the GABA transporter. In the absence of vigabatrin treatment, nonvesicular GABA efflux did not occur spontaneously but could be induced easily by a small increase in $\left[\mathrm{K}^{+}\right]_{\mathrm{o}}$. Thus, the direction of GABA flux through the GABA transporter is highly dynamic, the instantaneous direction being dependent on the [GABA] gradient and small changes in membrane potential near resting potential. These findings indicate that the GABA transporter is not important just for reuptake of GABA from the extracellular space but also for the release of GABA under conditions that occur physiologically.

It remains unclear whether neurons and/or glia are the source of GABA efflux. It has been shown previously that GABA can be released from neurons by reversal of the transporter (Schwartz, 1987; Wood et al., 1988; Taylor and Gordon-Weeks, 1991), but carrier-mediated GABA release also has been demonstrated from glia (Gallo et al., 1991). Although GABA levels are probably low in glia under normal conditions, this may not be the case after blockade of GABA transaminase.

\section{$\mathrm{GABA}_{\mathrm{A}}$ receptor activation as an assay of GABA release}

The use of electrophysiological recordings to measure $\mathrm{GABA}_{\mathrm{A}}$ receptor activation as an assay of GABA release allowed for detection of very small quantities of GABA release at a location that was biologically relevant, and with a fast response time. These methods were probably responsible for our ability to define how easily the GABA transporter reverses. Most previous studies of carrier-mediated GABA release have assayed extracellular GABA by using HPLC or radiolabeled GABA. This approach has a slow response time and is not sensitive to small local concentrations of GABA at sites where it is functionally significant, such as within the synaptic cleft. The GABA transporter also has been studied by measuring current flow directly through the transporter (Malchow and Ripps, 1990; Mager et al., 1993; Cammack et al., 1994; Risso et al., 1996). The time course of these current measurements is fast, but it is difficult to correlate current flow with the functional effect, i.e., GABA receptor activation. Measurement of current flow also may not be sensitive enough to record very small amounts of GABA flux that would be sufficient to activate $\mathrm{GABA}_{\mathrm{A}}$ receptors within the restricted intercellular space.

\section{Functional role of the GABA transporter}

The results presented here indicate that the GABA transporter operates near equilibrium under physiological conditions. A rise in $\left[\mathrm{K}^{+}\right]_{\mathrm{o}}$ from 3 to $6 \mathrm{~mm}$, or an increase in the cytosolic [GABA], was enough to alter the equilibrium so that GABA efflux occurred. It will be important to explain these observations in terms of the molecular mechanisms of transporter function. The traditional view of the GABA transporter is that it is electrogenic, with a fixed stoichiometry of two sodium ions and one chloride ion transported per GABA molecule (Larsson et al., 1980; Guastella et al., 1990; Borden et al., 1992; Kavanaugh et al., 1992; Mager et al., 1993). However, measurements of current flow through artificially expressed GAT-1 suggest that the stoichiometry actually is not fixed. For example, $\mathrm{Na}^{+}$or $\mathrm{Cl}^{-}$can be transported alone in the absence of GABA (Cammack et al., 1994). Because "uncoupled" $\mathrm{Na}^{+}$flux can occur without GABA flux, it is possible that uncoupled GABA flux also could occur in the absence of $\mathrm{Na}^{+}$or $\mathrm{Cl}^{-}$flux. Because GABA is uncharged, uncoupled GABA flux would not be detected by recordings of transporter current. This could explain how the direction of GABA transport could be so sensitive to cytosolic [GABA]. As cytosolic [GABA] increases sufficiently high, there may be significant "slippage" of the transporter, with uncoupled GABA efflux occurring without $\mathrm{NaCl}$ efflux. However, an alternative possibility is that GABA flux is coupled with $\mathrm{Na}^{+}$and $\mathrm{Cl}^{-}$under physiological conditions but that $\mathrm{Na}^{+}$is driven against its gradient when GABA efflux is induced by an increase in cytosolic [GABA].

Rather than simply acting as a sponge for reuptake of GABA after vesicular release, the GABA transporter apparently maintains an equilibrium between intracellular and extracellular neurotransmitter levels. The setpoint for this equilibrium depends on membrane potential and on the GABA, sodium, and chloride concentration gradients. The large increase in extracellular [GABA] after the fusion of synaptic vesicles would be expected to drive reuptake, but when extracellular [GABA] is low, nonvesicular GABA efflux commonly may occur at relatively low firing rates. Previous studies also have suggested that nonvesicular GABA efflux can be functionally important under some conditions (Schwartz, 1987; Taylor and Gordon-Weeks, 1991; During et al., 1995; Drew et al., 1997).

Reversal is not unique to the GABA transporter (Nicholls and Attwell, 1990; Levi and Raiteri, 1993), but it is possible that the threshold for reversal of the GABA transporter is lower than for other transporters (Attwell et al., 1993). A low threshold for reversal may be related to the inhibitory role of the GABAergic system. As neuronal activity increases, nonvesicular GABA release would help to brake excessive excitation. This negative feedback would be resistant to energy deprivation, because a decrease in ATP stores would enhance nonvesicular release by depolarizing cells and increasing $\left[\mathrm{Na}^{+}\right]_{\mathrm{i}}$. In contrast, if the glu-
A

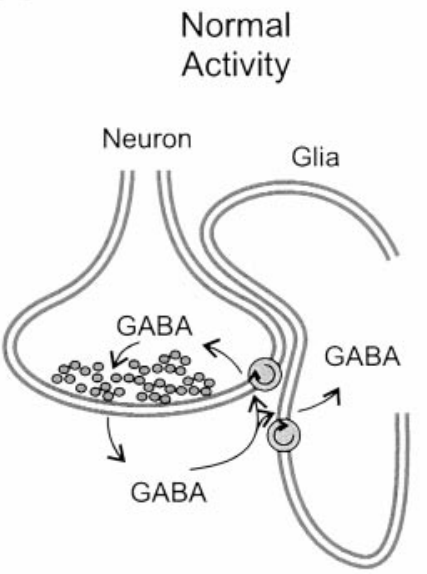

B High Frequency Firing / Seizures

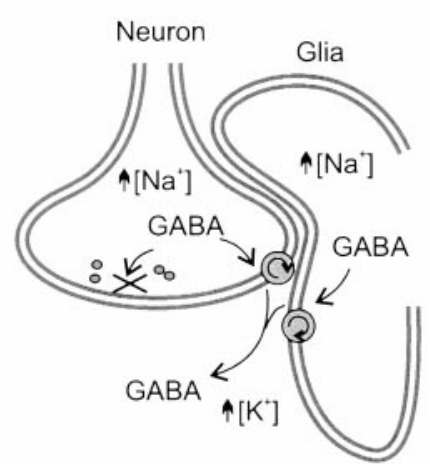

Figure 10. Model for dual role of the GABA transporter. Under normal conditions $(A)$ the GABA transporter works in the forward direction to clear the extracellular space of GABA. During high frequency firing and seizures $(B)\left[\mathrm{K}^{+}\right]_{\mathrm{o}}$ and $\left[\mathrm{Na}^{+}\right]_{\mathrm{i}}$ both rise, and the cells depolarize. This would induce a reversal of the GABA transporter, maintaining GABAergic inhibition at a time that vesicular release decreases. The source of GABA release (neurons or glia) is not known at present. 
tamate transporter had such a low threshold for reversal, it might induce excitotoxicity under normal conditions (Nicholls and Attwell, 1990).

\section{Anticonvulsant mechanism of vigabatrin}

The results presented here suggest that an increase in nonvesicular GABA release contributes to the anticonvulsant effect of vigabatrin. After an intraperitoneal injection of vigabatrin in vivo, the GABA pool associated with nerve terminals does not peak until $60 \mathrm{hr}$ (Gale and Iadarola, 1980). It is the level of GABA in this nerve terminal pool that correlates with anticonvulsant activity and not total GABA, which peaks in $<36 \mathrm{hr}$ (Gale and Iadarola, 1980). The slow increase in nonvesicular GABA efflux observed here in cultured cells mimics the time course of the anticonvulsant effect in vivo, suggesting that enhancement of nonvesicular GABA release contributes to the anticonvulsant effect. Because the bath solution did not contain vigabatrin at the time the recordings were made, the nonvesicular GABA release induced by vigabatrin was not a result of direct, reversible GABAergic actions of the drug (Jolkkonen et al., 1992; Jung and Palfreyman, 1995; Jackson et al., 2000).

Low concentrations of vigabatrin induced spontaneous nonvesicular GABA release and tonic inhibition of neighboring neurons, which might be assumed to be detrimental to brain function. However, tonic vesicular release of GABA occurs under physiological conditions in untreated tissue and has been proposed to be important for the regulation of neuronal excitability (Otis et al., 1991). Thus, tonic nonvesicular GABA release induced by therapeutic levels of vigabatrin simply may contribute to this background inhibitory tone and help to regulate neuronal firing. Higher doses of vigabatrin could result in excessive tonic inhibition or alternatively could result in desensitization of a population of $\mathrm{GABA}_{\mathrm{A}}$ receptors, leading to a decrease in inhibition.

When neuronal firing rates become excessive, vesicular GABA release decreases because of the depletion of energy stores and limitation of the maximum rate of recycling of vesicles (Fig. 10). Under these same conditions, nonvesicular GABA release would be stimulated. Vigabatrin thus would enhance a form of GABA release that is most important at high firing rates. This activitydependent mechanism would explain why vigabatrin prevents seizures with relatively little effect on normal cognition. A low incidence of cognitive side effects is a property shared with the anticonvulsant gabapentin, which shares the final common pathway of enhancement of nonvesicular GABA release (Kocsis and Honmou, 1994; Honmou et al., 1995; Taylor et al., 1998; Rho and Sankar, 1999).

Factors other than depolarization and cytosolic [GABA] can alter the function of the GABA transporter and thus may reduce or enhance its role during seizures. Dynamic insertion of GABA transporters into the plasma membrane has been demonstrated to occur in response to an increase in extracellular [GABA] (Bernstein and Quick, 1999). An increased number of GABA transporters in the plasma membrane would increase the flux of GABA under the force of a constant [GABA] gradient. Conversely, within the seizure focus of human temporal lobe epilepsy patients there is evidence for a decrease in the number of functional GABA transporters (During et al., 1995), which could contribute to seizure generation or spread. It is likely that a variety of other factors could modulate GABA transporter number or alter the function of those transporters that are present.

We propose that nonvesicular GABA release is an important form of inhibition that complements vesicular GABA release. A variety of pathological processes, physiological modulators, and pharmacological agents may alter the balance between GABA reuptake and carrier-mediated GABA release and thus influence neuronal excitability and seizure susceptibility.

\section{REFERENCES}

Attwell D, Barbour B, Szatkowski M (1993) Nonvesicular release of neurotransmitter. Neuron 11:401-407.

Belhage B, Hansen GH, Schousboe A (1993) Depolarization by $\mathrm{K}^{+}$and glutamate activates different neurotransmitter release mechanisms in GABAergic neurons: vesicular versus nonvesicular release of GABA. Neuroscience 54:1019-1034.

Ben-Menachem E, Hamberger A, Mumford J (1993) Effect of long-term vigabatrin therapy on GABA and other amino acid concentrations in the central nervous system - a case study. Epilepsy Res 16:241-243.

Bernath S, Zigmond MJ (1988) Characterization of [ $\left.{ }^{3} \mathrm{H}\right] \mathrm{GABA}$ release from striatal slices: evidence for a calcium-independent process via the GABA uptake system. Neuroscience 27:563-570.

Bernstein EM, Quick MW (1999) Regulation of $\gamma$-aminobutyric acid (GABA) transporters by extracellular GABA. J Biol Chem 274:889-895

Borden LA, Smith KE, Hartig PR, Branchek TA, Weinshank RL (1992) Molecular heterogeneity of the $\gamma$-aminobutyric acid (GABA) transport system: cloning of two novel high affinity GABA transporters from rat brain. J Biol Chem 267:21098-21104.

Cammack JN, Schwartz EA (1993) Ions required for the electrogenic transport of GABA by horizontal cells of the catfish. J Physiol (Lond) 472:81-102.

Cammack JN, Rakhilin SV, Schwartz EA (1994) A GABA transporter operates asymmetrically and with variable stoichiometry. Neuron 13:949-960.

Cherubini E, Gaiarsa JL, Ben-Ari Y (1991) GABA: an excitatory transmitter in early postnatal life. Trends Neurosci 14:515-519.

Connors BW, Prince DA (1982) Effects of local anesthetic QX-314 on the membrane properties of hippocampal pyramidal neurons. J Pharmacol Exp Ther 220:476-481.

Drew KL, Fitka T, Hu Y, Ungerstedt U (1997) Non-exocytotic GABA overflow in rat striatum inhibits gnawing. Life Sci 61:1593-1601.

During MJ, Ryder KM, Spencer DD (1995) Hippocampal GABA transporter function in temporal-lobe epilepsy. Nature 376:174-177.

Engel D, Endermann U, Frahm C, Heinemann U, Draguhn A (2000) Acute effects of gamma-vinyl-GABA on low-magnesium evoked epileptiform activity in vitro. Epilepsy Res 40:99-107.

Fisher RS, Pedley TA, Moody Jr WJ, Prince DA (1976) The role of extracellular potassium in hippocampal epilepsy. Arch Neurol 33:76-83.

Gale K, Iadarola MJ (1980) Seizure protection and increased nerveterminal GABA: delayed effects of GABA transaminase inhibition. Science 208:288-291.

Gallo V, Patrizio M, Levi G (1991) GABA release triggered by the activation of neuron-like non-NMDA receptors in cultured type 2 astrocytes is carrier-mediated. Glia 4:245-255.

Gaspary HL, Wang W, Richerson GB (1998) Carrier-mediated GABA release activates GABA receptors on hippocampal neurons. J Neurophysiol 80:270-281.

Gram L, Larsson OM, Johnsen AH, Schousboe A (1988) Effects of valproate, vigabatrin and aminooxyacetic acid on release of endogenous and exogenous GABA from cultured neurons. Epilepsy Res 2:87-95.

Greenfield Jr LJ, Macdonald RL (1996) Whole-cell and single-channel $\alpha_{1} \beta_{1} \gamma_{2}$ GABA $_{\mathrm{A}}$ receptor currents elicited by a "multipuffer" drug application device. Pfl $\int$ gers Arch 432:1080-1090.

Guastella J, Nelson N, Nelson H, Czyzyk L, Keynan S, Miedel MC, Davidson N, Lester H, Kanner B (1990) Cloning and expression of a rat brain GABA transporter. Science 249:1303-1306.

Honmou O, Kocsis JD, Richerson GB (1995) Gabapentin potentiates the conductance increase induced by nipecotic acid in CA1 pyramidal neurons in vitro. Epilepsy Res 20:193-202.

Jackson MF, Dennis T, Esplin B, Capek R (1994) Acute effects of gamma-vinyl GABA (vigabatrin) on hippocampal GABAergic inhibition in vitro. Brain Res 651:85-91.

Jackson MF, Esplin B, Capek R (2000) Reversal of the activitydependent suppression of GABA-mediated inhibition in hippocampal slices from gamma-vinyl GABA (vigabatrin)-pretreated rats. Neuropharmacology 39:65-74

Jolkkonen J, Mazurkiewicz M, Lahtinen H, Riekkinen P (1992) Acute effects of gamma-vinyl GABA on the GABAergic system in rats as studied by microdialysis. Eur J Pharmacol 229:269-272.

Jung MJ, Palfreyman MG (1995) Vigabatrin. Mechanisms of action. In: Antiepileptic drugs (Levy RH, Mattson RH, Meldrum BS, eds), pp 903-913. New York: Raven.

Kavanaugh MP, Arriza JL, North RA, Amara SG (1992) Electrogenic uptake of $\gamma$-aminobutyric acid by a cloned transporter expressed in Xenopus oocytes. J Biol Chem 267:22007-22009. 
Kocsis JD, Honmou O (1994) Gabapentin increases GABA-induced depolarization in rat neonatal optic nerve. Neurosci Lett 169:181-184.

Krnjevic K, Morris ME, Reiffenstein RJ (1980) Changes in extracellular $\mathrm{Ca}^{2+}$ and $\mathrm{K}^{+}$activity accompanying hippocampal discharges. Can J Physiol Pharmacol 58:579-582.

Kyrozis A, Reichling DB (1995) Perforated-patch recording with gramicidin avoids artifactual changes in intracellular chloride concentration. J Neurosci Methods 57:27-35.

Larsson OM, Hertz L, Schousboe A (1980) GABA uptake in astrocytes in primary cultures: coupling with two sodium ions. J Neurosci Res 5:469-477.

Levi G, Raiteri M (1993) Carrier-mediated release of neurotransmitters. Trends Neurosci 16:415-419.

Loscher W, Horstermann D (1994) Differential effects of vigabatrin, gamma-acetylenic GABA, aminooxyacetic acid, and valproate on levels of various amino acids in rat brain regions and plasma. Naunyn Schmiedebergs Arch Pharmacol 349:270-278.

Mager S, Naeve J, Quick M, Labarca C, Davidson N, Lester HA (1993) Steady states, charge movements, and rates for a cloned GABA transporter expressed in Xenopus oocytes. Neuron 10:177-188.

Malchow RP, Ripps H (1990) Effects of $\gamma$-aminobutyric acid on skate retinal horizontal cells: evidence for an electrogenic uptake mechanism. Proc Natl Acad Sci USA 87:8945-8949.

Meldrum BS (1975) Epilepsy and $\gamma$-aminobutyric acid-mediated inhibition. Int Rev Neurobiol 17:1-36.

Moscowitz JA, Cutler RW (1980) Bidirectional movement of $\gamma$-aminobutyric acid in rat spinal cord slices. J Neurochem 35:1394-1399.

Nicholls D, Attwell D (1990) The release and uptake of excitatory amino acids. Trends Pharmacol Sci 11:462-468.

Otis TS, Staley KJ, Mody I (1991) Perpetual inhibitory activity in mammalian brain slices generated by spontaneous GABA release. Brain Res 545:142-150.

Petroff OA, Behar KL, Mattson RH, Rothman DL (1996) Human brain $\gamma$-aminobutyric acid levels and seizure control following initiation of vigabatrin therapy. J Neurochem 67:2399-2404.

Pin JP, Bockaert J (1989) Two distinct mechanisms, differentially affected by excitatory amino acids, trigger GABA release from fetal mouse striatal neurons in primary culture. J Neurosci 9:648-656.

Preece NE, Jackson GD, Houseman JA, Duncan JS, Williams SR (1994) Nuclear magnetic resonance detection of increased cortical GABA in vigabatrin-treated rats in vivo. Epilepsia 35:431-436.

Qume M, Whitton PS, Fowler LJ (1995) The effect of chronic treatment with the GABA transaminase inhibitors gamma-vinyl-GABA and ethanolamine- $O$-sulphate on the in vivo release of GABA from rat hippocampus. J Neurochem 64:2256-2261.
Rae J, Cooper K, Gates P, Watsky M (1991) Low access resistance perforated patch recordings using amphotericin B. J Neurosci Methods 37:15-26.

Rho JM, Sankar R (1999) The pharmacologic basis of antiepileptic drug action. Epilepsia 40:1471-1483.

Risso S, DeFelice LJ, Blakely RD (1996) Sodium-dependent GABAinduced currents in GAT1-transfected HeLa cells. J Physiol (Lond) 490:691-702.

Rivera C, Voipio J, Payne JA, Ruusuvuori E, Lahtinen H, Lamsa K, Pirvola U, Saarma M, Kaila K (1999) The $\mathrm{K}^{+} / \mathrm{Cl}^{-}$co-transporter KCC2 renders GABA hyperpolarizing during neuronal maturation. Nature 397:251-255.

Saransaari P, Oja SS (1992) Release of GABA and taurine from brain slices. Prog Neurobiol 38:455-482.

Schechter PJ, Tranier Y, Jung MJ, Bohlen P (1977) Audiogenic seizure protection by elevated brain GABA concentration in mice: effects of gamma-acetylenic GABA and gamma-vinyl GABA, two irreversible GABA-T inhibitors. Eur J Pharmacol 45:319-328.

Schwartz EA (1987) Depolarization without calcium can release $\gamma$-aminobutyric acid from a retinal neuron. Science 238:350-355.

Solis JM, Nicoll RA (1992) Postsynaptic action of endogenous GABA released by nipecotic acid in the hippocampus. Neurosci Lett 147:16-20.

Somjen G, Giacchino JL (1985) Potassium and calcium concentrations in interstitial fluid of hippocampal formation during paroxysmal responses. J Neurophysiol 53:1098-1108.

Staley KJ, Soldo BL, Proctor WR (1995) Ionic mechanisms of neuronal excitation by inhibitory $\mathrm{GABA}_{\mathrm{A}}$ receptors. Science 269:977-981.

Taylor CP, Gee NS, Su TZ, Kocsis JD, Welty DF, Brown JP, Dooley DJ, Boden P, Singh L (1998) A summary of mechanistic hypotheses of gabapentin pharmacology. Epilepsy Res 29:233-249.

Taylor J, Gordon-Weeks PR (1991) Calcium-independent $\gamma$-aminobutyric acid release from growth cones: role of $\gamma$-aminobutyric acid transport. J Neurochem 56:273-280.

Turner TJ, Goldin SM (1989) Multiple components of synaptosomal $\left[{ }^{3} \mathrm{H}\right]-\gamma$-aminobutyric acid release resolved by a rapid superfusion system. Biochemistry 28:586-593.

Wang W, Pizzonia JH, Richerson GB (1998) Chemosensitivity of rat medullary raphe neurones in primary tissue culture. J Physiol (Lond) 511:433-450.

Wood JD, Kurylo E, Lane R (1988) $\gamma$-Aminobutyric acid release from synaptosomes prepared from rats treated with isonicotinic acid hydrazide and gabaculine. J Neurochem 50:1839-1843.

Yee JM, Agulian S, Kocsis JD (1998) Vigabatrin enhances promoted release of GABA in neonatal rat optic nerve. Epilepsy Res 29:195-200. 